\title{
«Приезжий из столицы, или Суматоха в уездном городе» и «Ревизор»
}

\author{
ВИКТОРИЯ ЛЕБОВИЧ \\ LEBovics Viktória, ELTE BTK Ukrán Filológiai Tanszék, H-1088 Budapest, Múzeum krt. 4/D. \\ Department of Ukrainian Studies, Faculty of Humanities, Eötvös Loránd University \\ E-mail: leboviki@gmail.com
}

(Received: 6 December 2017; accepted: 3 February 2018)

\begin{abstract}
The Ukrainian writer and playwright Hryhory Kvitka-Osnovyanenko wrote his satirical drama The Visitor from the Capital or Turmoil in a District Town in 1827 but it was published only in 1840, while Nikolai Gogol's play The Government Inspector was brought out in 1835. The topic of the incognito traveller, a false government inspector whom the threatened town officials attempt to suborn in different ways, circulated in the imperial Russian society at that time. The possible influence of Kvitka's play on the famous The Government Inspector is a question which has excited the imagination of literary critics since the middle of 19th century although they have treated it quite differently. The range of opinions varies from the complete rejection of the possibility to suspect plagiarism, irrespective of the fact that Gogol himself denied he was familiar with his Ukrainian fellow writer's play. An overview of opinions and articles devoted to the question is presented in the paper.
\end{abstract}

Keywords: Nikolai Gogol, Hryhory Kvitka-Osnovyanenko, Ukrainian playwright, satiric drama, literary influence

Цикл радиопередач для школьников средних и старших классов под названием «В стране литературных героев», авторами которых были С. Рассадин и Б. Сарнов, звучал в эфире СССР, а потом России с 1970 по 1989 год. В пятом путешествии, озаглавленном «Вторая ошибка Шерлока Холмса», главные герои радиопередач школьник Гена и профессор Архип Архипович просят Шерлока Холмса помочь им распутать весьма загадочное дело. Излагая его суть, Архип Архипович приступает к рассказу об истории создания пьесы, которая начинается с того, что в России в двадцатых годах девятнадцатого века в маленьком уездном городе городничий получает письмо и рассказывает всем известные дальнейшие события, однако возмущенный Холмс прерывает его:

Позвольте, я не понимаю, к чему вы мне все это рассказываете? Неужто вы полагаете, что я не читал «Ревизора», комедию вашего великого писателя Гоголя?

А. А.: Вы ошибаетесь. Я рассказываю вам сейчас содержание отнюдь не гоголевского «Ревизора». Речь идет о полузабытой пьесе одного современника Гоголя, некоего Квитки-Основьяненко. Пьеса эта называлась «Приезжий из столицы, или Суматоха в уездном городе». 
Холмс: (у него пробуждается чисто профессиональный интерес). Вот как? А в каком году этот самый Квитка написал свою пьесу?

А. А.: В тысяча восемьсот двадцать седьмом.

Холмс: Так-так! А «Ревизор» был написан...

А. А.: (понимает, куда клонит Холмс). Да, в тысяча восемьсот тридцать пятом. Но впервые напечатана комедия Квитки была только в тысяча восемьсот сороковом году, то есть через четыре года после первой постановки гоголевского «Ревизора». И сам Гоголь уверял, что комедию Квитки он не читал...

(РАССАДИН-САРНОВ 2002)

Архип Архипович сообщает Холмсу также, что Пушкин сам хотел написать произведение о мнимом ревизоре, но потом уговорил это сделать Гоголя. Известному лондонскому сыщику для раскрытия дела этого достаточно: Гоголь заимствовал сюжет своего «Ревизора» у Квитки, и

чтобы избежать обвинения в плагиате, он решил при этом создать себе так называемое ложное алиби. С этой целью он распространил слух, что сюжет «Ревизора» ему подарил Пушкин... Как видите, дорогой профессор, для человека, владеющего дедуктивным методом, в этой истории нет решительно ничего загадОчНОГо! (РАССАДИН-САРНОВ 2002).

Итак, Шерлок Холмс абсолютно уверен в том, чему до сих пор еще никто не нашел однозначных доказательств, потому что документальных свидетельств о знакомстве Гоголя с рукописью Квитки нет.

О первой русскоязычной комедии Г. Квитки-Основьяненко В. И. Мацапура в статье «,Ревизор“ Гоголя и „Приезжий из столицы“ Г. Ф. Квитки-Основьяненко (типологический аспект)» в 2008 году написал, что она в свое время была известна и даже служила предметом споров, но сегодня о ней помнят разве что узкие специалисты. Читателям, в том числе и студентам украинских отделений она неизвестна (МАцАПурА 2008).

Комедия была опубликована в 1840 году без ведома автора в «Пантеоне русского и всех европейских театров» с указанием того, что написана она была в 1827 году и разрешена цензором С. Т. Аксаковым (под номером 602) к печати уже в следующем 1828 году. Рукопись тогда же была отправлена в Петербург, «ходила там по рукам, ходила по Москве», по украинским землям и возвратилась в Харьков только в тридцатые годы (МАцАПурА 2008).

Комедия Г. Квитки-Основьяненко по своей художественной ценности уступает произведению Н. Гоголя, на что намекал и В. Г. Белинский, когда писал:

Мы так высоко уважаем прекрасный талант Грыцька Основьяненко, что ничего не скажем об этом его произведении, которого талантливый автор очень и очень не без причины не хотел так долго печатать (БЕлинский 1978: 408).

Сам украинский писатель в письме от 18 мая 1840 года к Ф. А. Кони (1809-1879) также пишет об этом: 
Куда ему [т. е. «Приезжему» - В. Л.] между добрых людей показываться? [...] Никогда не должно идти ничто в сравнение с пьесою всем известного, всеми любимого и признанною неподражаемою. Выигрыш невозможен, и сравнения всегда будут не в пользу последнего. Потому-то я и спрятал его, когда вышел «Ревизор» (КВітКА-Основ’яненко 1981: 251).

И дальше:

Сказав Вам мнение о моем «Приезжем» напечатанном, посудите, могу ли согласиться пустить его на сцену? [...] После «Ревизора» он точно не будет так занимателен... Не все же будут знать, что комедия написана прежде «Ревизора»; не все будут знать, что я безо всего отдал на сцену, а припишут и сему, и тому, и бог знает чему! Вот почему не хочется мне выставить ее на поругание... (КВіТКА-ОСНОВ'яНЕНКО 1981: 252).

Однако все это Квитка-Основьяненко напишет позже. А в 1836 году согласно воспоминаниям писателя Григория Петровича Данилевского (18291890), издавшего в 1866 году сборник исторических и биографических очерков под названием «Украинская старина»: «Ознакомясь съ „Ревизоромъ“ и зная близость С. Т. Аксакова къ Гоголю, Квитка пришель въ неописанное смущеніе» (ДАнилевский 1893). Ю. В. Розанов в своей статье «Н. В. Гоголь и Г. Ф. Квитка-Основьяненко: история одного совпадения», увидевшей свет в 2008 году, ссылаясь также на Данилевского, утверждает, что Квитка, получив первый экземпляр «Ревизора» в Харькове, пришел в негодование, созвал к себе в дом всех своих знакомых и прочитал им подряд сначала свою, а потом комедию Гоголя. «Гости ахнули и сказали в один голос, что комедия Гоголя целиком взята из его сюжета и по характеристикам, и даже по частной обстановке» (Розанов 2008). Более того, после премьеры «Ревизора» Квитка в 1836 году послал свое произведение в Дирекцию московских театров, однако директор М. Н. Загоскин несмотря на то, что похвалил комедию, отказался принять произведение Квитки, утверждая, что «Публика всегда чрезвычайно строга к подражаниям, а уверить ее едва ли будет можно, что эта комедия написана прежде комедии г. Гоголя» (ЗАГоскин 1987: 732).

По просьбе Данилевского Аксаков с целью выяснения вопроса обратился непосредственно к самому Гоголю:

Я спрашивал Гоголя (около 1840 г.), не знает ли он эту комедию? И он отвечал мне, что слышал о ней, но не читал (ДАнилЕвский 1866: 217).

После констатации данного утверждения, кажущегося решающим с точки зрения истории написания двух произведений, С. Т. Аксаков делает вывод о том, что анекдоты о ложных ревизорах в разных вариациях вне всякого сомнения уже давно ходили по России, и именно это натолкнуло обоих авторов на мысль отразить это в художественном произведении (РозАнов 2008). О. И. Сеньковский в «Библиотеке для чтения» в 1836 г. после выхода в свет комедии Гоголя писал об анекдоте, легшем в ее основу, что он «тысячу раз 
напечатанный, рассказанный и обделанный в разных видах» (ЗАЙцЕВА-МАНн 2003: 639).

По свидетельству О. М. Бодянского на вечере в доме С. Т. Аксакова 31 октября 1851 года Гоголь «...при разговоре между прочим заметил, что первую идею к „Ревизору“ ему подал Пушкин, рассказав историю о Павле Петровиче Свиньине...» (Бодянский 1952: 431). Граф В. А. Соллогуб, описывая свою первую встречу с Гоголем летом 1831 года, повествует о якобы рассказанной Пушкиным Гоголю истории «про случай, бывший в г. Устюжне Новгородской губернии, о каком-то проезжем господине, выдавшем себя за чиновника министерства и обобравшем всех городских жителей» (Соллогуь 1952: 78). С Устюжной связан еще один вариант рассказа, описанный потомком Батюшкова в газетной статье под названием «Знал ли Гоголь Россию?» (ЗАЙЦЕВА-МАнн 2003: 637). Да и сам Пушкин в полученном В. А. Перовским письме был обвинен в том, что «должно быть ему дано тайное поручение собирать сведения о неисправностях» (Соллогуь 1952: 78). Не стоит забывать также, что и сам Гоголь в августе 1835 года по воспоминаниям Данилевского сыграл ревизора, только не на сцене, а в жизни:

Гоголь хотел основательно изучить впечатление, которое произведет на станционных смотрителей его ревизия с мнимым инкогнито. Для этой цели он просил Пашенка выезжать вперед и распространять везде, что следом за ним едет ревизор, тщательно скрывающий настоящую цель своей поездки... (ЗАЙЦЕВАМАНн 2003: 639).

Принимая к сведению переданное через Аксакова утверждение Гоголя, Г. П. Данилевский все же приходит к выводу о том, что

нельзя не придти къ мысли, что внђшній планъ, рамки «Ревизора» могли быть даны Гоголю его другомъ, С. Т. Аксаковымъ, который, въ качествђ цензора, прочель пьесу Квитки... (ДАнилЕвСКий 1893).

В научном обороте утвердилась точка зрения Аксакова, однако вопрос о возможной связи между произведениями продолжал обсуждаться. Смерть Г. Квитки-Основьяненко в 1843 году вызвала продолжение дискуссии. Например, Якив Головацкий (1814-1888) в своей статье «О житті і сочиненіях Грицька Основ'яненка», подчеркивает «близьке подобеньство із „Ревізором“ Гоголя, далеко пізніше появившимся в світі» (ГоловАцький 1996: 170). Касались вопроса также Ф. А. Кони в «Литературной газете» (1843), К. М. Сементковский в «Москвитянине» (1843), Н. В. Сушков в «Рауте» (1854), Н. Г. Марков в «Киевской старине» (1883), К. И. Петров в своей работе «Очерки украинской литературы ХІХ столетія» (1884) (Волков 1899: 59-60). Вместе с тем «самый старый» биограф Гоголя Пантелеймон Кулиш полностью обошел молчанием сходство двух произведений (Волков 1899: 61).

В начале XX столетия дискуссия о взаимовлиянии возобновилась, не в последнюю очередь благодаря тому, что «рубеж веков и начало ХХ столетия в литературной жизни России отмечены особым интересом к заимствова- 
ниям, в том числе и к заимствованиям в грубых формах плагиата» (РозАнов 2008). Н. В. Волков в своей статье «Кь исторіи русской комедіи. Зависимость „Ревизора“ Гоголя оть комедіи Квитки „Пріњзжій изъ столицы“” (1899), явно ориентированной на сенсацию (РозАнов 2008), приходит к следующему выводу: «...комедія Гоголя „Ревизоръ“ несомнънно создалась подъ вліяніемъ комедіи Квитки» и можно «...установить факть, что Гоголь не только читаль комедію Квитки, но и пользовался ею при сочиненіи своего „Ревизора“...» (Волков 1899: 54, 63). Отмечая, что трудно понять, почему Гоголь нигде и никогда не упоминает имени Квитки, «какъ будто для него онъ вовсе не существовалъ» (Волков 1899: 58), Волков заканчивает свой временами достаточно запутанный и неубедительный сопоставительный анализ двух произведений следующими словами:

Да простить память Гоголя, если теперь дъйствительно раскрылась та тайна, въ которую онъ не пожелаль посвятить даже ближайшихъ своихъ друзей (Волков 1899: 64).

В 1902 г. А. И. Лященко в работе «,Ревизор“ Гоголя и комедія Квитки „Пріњзжій изъ столицы“» вступил в полемику с Волковым:

Намъ представляется, что критикъ, желающій выяснить взаимоотношенія двухъ близкихъ по сюжету произведеній, долженъ обратить вниманіе не на мелочи, случайно сходныя, а возможно рельефно проанализировать типы дъйствующихъ лицъ и указать точки соприкосновенія и различія. Г. Волковъ поступилъ иначе (Лященко 1902: 6).

По поводу размышлений Волкова о том, что перенял, что опустил и что куда перенес Гоголь по сравнению с комедией Квитки, Лященко замечает: «Читая эти строки г. Волкова, поневоле развъдешь руками. Съ такими пріемами критики можно доказать все, что угодно» (ЛящЕнко 1902: 14).

Н. Котляревский в своей книге «Николай Васильевич Гоголь. 1829-1842. Очерк из истории русской повести и драмы», вышедшей в свет в 1903 году, также отвергает выводы Волкова и объясняет сходство двух произведений особенностями самозарождения сюжета. Среди прочего вспоминает сборник анекдотов и сатирических очерков Н. Полевого (1832) с маленькой драматической сценкой, озаглавленной «Ревизоры, или Славны бубны за горами», напоминающей сюжет «Ревизора» (КотляРЕвСКий 1903: 83).

А И. Я. Айзеншток в 1919 г. в статье «К вопросу о литературных влияниях (Г. Ф. Квитка и Н. В. Гоголь)» прямо заявил: «...легенда о влиянии комедии Квитки на „Ревизора“, вошедшая довольно прочно в литературный обиход, должна быть отвергнута раз навсегда» (РозАнов 2008).

Показательно, что еще через десять лет В. В. Виноградов в своей работе «Эволюция русского натурализма. Гоголь и Достоевский» все же поддерживает тех, кто говорит о зависимости двух произведений. Ученый в сноске к тексту мнения Айзенштока называет «странными размышлениями о взаи- 
моотношениях Гоголя и Квитки» (Виноградов 1929: 333). В. В. Виноградов отмечает, что современники часто называли Квитку и Гребенку последователями Гоголя:

Но на самом деле отношение этих писателей, особенно Квитки, к Гоголю было чрезвычайно сложное. [...] Спорный вопрос о зависимости «Ревизора» Гоголя от комедии Квитки - «Приезжий из столицы», по моему мнению, правильнее решать в положительную сторону. По крайней мере трудно сомневаться в знакомстве Гоголя с нею и с ее литературной традицией в эпоху работы над «Ревизором»; о распространенности этой комедии в литературных кругах $30-\mathrm{x}$ годов можно судить по тому, что один из очень популярных тогда писателей $[\ldots]$ Вельтман, в начале 1835 г. печатает в «Библиотеке для чтения» полукомедию, полуновеллу - «Провинциальные актеры», где влияние комедии Квитки и прозрачнее и сильнее, чем в «Ревизоре» Гоголя (Виноградов 1929: 332-333).

На время дискуссия прерывается и вопрос о влиянии-заимствовании одного произведения на другое ставится в форме своеобразных напоминаний в связи с годовщинами рождения и смерти Григория Квитки-Основьяненко, как, например, в популярной радиопередаче Бенедикта Сарнова и Станислава Рассадина 70-х годов. В 1979 году в исполнении труппы Московского театра им. Маяковского комедия Григория Квитки-Основьяненко прозвучала по радио. Слушателям было предложено самим сделать вывод о возможном заимствовании:

Написанная и посланная в Петербург для прохождения цензуры, пьеса затерялась среди бумаг в чиновных кабинетах или среди чиновных читателей. Был ли среди них Николай Васильевич Гоголь и сколь много из одной пьесы попало в другую? Вот вопрос, на который вы сами можете дать ответ, прослушав запись спектакля (http://teatr.audio/kvitka-osnovyanenko-g-priezzhii-iz-stolicy).

В харьковской «Комсомольской правде» Оксана Якушко 18 ноября 2008 года по поводу 230-летия со дня рождения Квитки-Основьяненко опубликовала интервью с исследователем творчества писателя Александром Борзенко, пополнившим малоизвестными фактами биографию классика украинской литературы. Интересно, что журналист в названии интервью ставит прямой вопрос о плагиате: «Гоголь украл „Ревизора“ у Квитки-Основьяненко?». На что Борзенко отвечает, что нет ничего удивительного в том, что одинаковая идея посетила сразу двух авторов (Якушко 2008).

А канадский литературовед Юрий Луцкий в своей работе «Страдництво Миколи Гоголя, знаного також як Ніколай Гоголь» считает, что искать ответ на вопрос не стоит: «Неістотно, у кого Гоголь запозичив сюжет: у Квітки („Приезжий из столицы“) чи у Пушкіна» (Луцький 2002: 58).

В 4-м томе полного собрания сочинений и писем Н. В. Гоголя составители комментариев И. А. Зайцева и Ю. В. Манн отмечают, что связь «Ревизора» и «Приезжего из столицы» колеблется от «признания полной зависимости» до полного ее отрицания. 
Тем не менее проблему еще нельзя считать закрытой: при всей оригинальности художественной концепции «Ревизора» бросается в глаза сходство многих подробностей в обеих комедиях [...]. Однако, возможно, причина этого сходства в том, что Гоголь владел некоторой устной информацией $[\ldots]$, которая, как известно, также способна оказывать стимулирующее творческое воздействие... (ЗАЙЦЕВА-МАНН 2003: 649).

Станислав Рассадин в 2001 году в любопытной статье «Похвальное слово черновикам» формулирует интересную идею о том, что существуют такие произведения, которые становятся «черновиками-набросками» работ «беловиков-завершений» других авторов. «Беловиком» можно считать «Ревизора» Гоголя, для которого черновиком было произведение Квитки. По мнению Рассадина при таких явлениях необязательно предполагать взаимовлияние:

Был ли плагиат? Гоголь клялся, что нет. Поверим - тем более сюжет о лжеревизоре был ходовым (РАССАДИН 2001).

Абсолютно поразительным исследователь считает тот факт, что Квитка «поставил черновик» не только для Гоголя, но и для Сухово-Кобылина:

Дело в том, что у гениальной «Смерти Тарелкина» [...] тоже была предшественница в виде Квиткиной же комедии «Мертвец-шалун». Там в точности тот же фабульный ход и множество более частных совпадений, причем на сей раз можно, по-видимому, уверенно сказать: Сухово-Кобылину та комедия не была известна (РАССАДИН 2001).

\section{Литература}

АЙЗЕнштоК 1922 = АйЗЕншток И. К вопросу о литературных влияниях (Г. Ф. Квитка и Н. В. Гоголь). Известия Отделения русского языка и словесности Российской Академии наук 1919 г. Т. 24. Кн. 1. Петроград, 1922. 23-42.

БЕЛИНСКИй 1978 = БЕлинский В. Г. Пантеон русского и всех европейских театров. В кн.: БЕЛИнский В. Г. Собрание сочинений в 9 томах. Т. 3. Статьи, рецензии и заметки. Февраль 1840 - февраль 1841. Москва, 1978. 405-410.

Бодянский 1952 = Бодянский О. М. Из дневников. В кн.: Гоголь в воспоминаниях современников. Москва, 1952. 428-433.

ВИНОГРАДОВ $1929=$ ВИНОГРАДОВ В. В. Эволюиия русского натурализма. Гоголь и Достоевский. Ленинград, 1929.

Волков 1899 = Волковъ Н. В. Къ исторіи русской комедіи. Зависимость «Ревизора» Гоголя отъ комедіи Квитки «Пріъзжій изъ столиць»». Санкт-Петербургъ, 1899. https://www.litres.ru/static/or3/view/or.html?art type=4\&file=1228665.

ГоловАцький 1996 = ГоловАцьКий Яків: О житті і сочиненіях Грицька Основ'яненка. В кн.: Історія української літературної критики та літературознавства. Хрестоматія. Кн. 1. Київ, 1996. 169-173.

ДАнилЕВСКиЙ $1866=$ ДАнилЕвСКий Г. П. Григорий Федорович Квитка-Основьяненко. В кн.: ДАнилевский Г. П. Украинская старина. Материаль для истории украинской литературы и народного образования. Харьков, 1866. 173-284. 
ДАнилЕВСКий $1893=$ ДАниЛЕвСКий Г. П. Григорій Өедоровичъ Квитка-Основьяненко (1778-1843). В кн.: Сочиненія Г. П. Данилевскаго (1847-1890). Т. 8. Санкт-Петербургъ, 1893.http://az.lib.ru/d/danilewskij_g_p/text_04_1855_starina_oldorfo.shtml.

ЗАГОСКИН 1987 = ЗАГОсКИн М. Н. Письмо Г. Ф. Квитке-Основьяненко от 10 ноября 1836 г. В кн.: ЗАГоскин М. Н. Сочинения. Т. 2. Комедии. Проза. Стихотворения. Письма. Москва, 1987. 732.

ЗАЙЦЕВА-МАНН 2003 = ЗАЙЦЕВА И. А., МАНН Ю. В. Комментарий. В кН.: ГОГОЛЬ Н. В. Полное собрание сочинений и писем в 23 томах. Т. 4. Москва, 2003. 537-888.

КВІТКА-ОСНОВ'яНЕНКО 1981 = КВІТКА-ОСНОВ'яНЕНКО Г. Ф. Письмо от 18 мая 1840 г. к Ф. А. Кони. В кн.: КвІтКА-Основ'яненко Г. Ф. Зібрання творів у 7 томах. Т. 7. Історичні, етнографічні, літературно-публіцистичні статті. Листи. Київ, 1981. 251-252.

КОТЛЯРЕВСКИй 1903 = КОТЛЯРЕВСКИй Н. Николай Васильевич Гоголь: 1829-1842. Очерк из истории русской повести и драмы. http://books.e-heritage.ru/book/10085694.

Луцький 2002 = Луцький Юрій: Страдництво Миколи Гоголя, знаного також як Ніколай Гоголь. Київ, 2002.

ЛЯщЕнко 1902 = ЛящЕнко А. І. «Ревизоръ» Гоголя и комедія Квитки «Пріђзжій изъ столиць»». Отдъльный оттискъ изъ сборника «Памяти Л. Н. Майкова». СанктПетербургъ, 1902. https://vivaldi.nlr.ru/bx000005744/view.

МАЦАПУРА 2008 = МАЦАПУРА В. И. «Ревизоръ» Гоголя $и$ «Приезжсий из столицы » Г.Ф.Квитки-Основьяненко (типологический аспект). http://domgogolya.ru/science/ researches/1026/.

РАССАДИН 2001 = РАССАдИН Станислав: Похвальное слово черновикам. Литература 2001/20. http://lit.1 september.ru/article.php?ID=200102007.

РАССАДИН-САРНОВ 2002 = РАССАДИН СТанислав, САРНОВ Бенедикт: В стране литературных героев. https://www.e-reading.club/book.php?book=50717.

Розанов 2008 = Розанов Ю. В. Н. В. Гоголь и Г. Ф. Квитка-Основьяненко: история одного совпадения. http://domgogolya.ru/science/researches/1031/.

Соллогуь 1952 = Соллогуь В. А. Первая встреча с Гоголем. В кн.: Гоголь в воспоминаниях современников. Москва, 1952. 75-78.

Якушко 2008 = Якушко Оксана: Гоголь украл «Ревизора» у Квитки-Основьяненко? Комсомольская правда в Украине, 18 ноября 2008 года. http://kp.ua/culture/62846hohol-ukral-revyzora-u-kvytky-osnovianenko. 